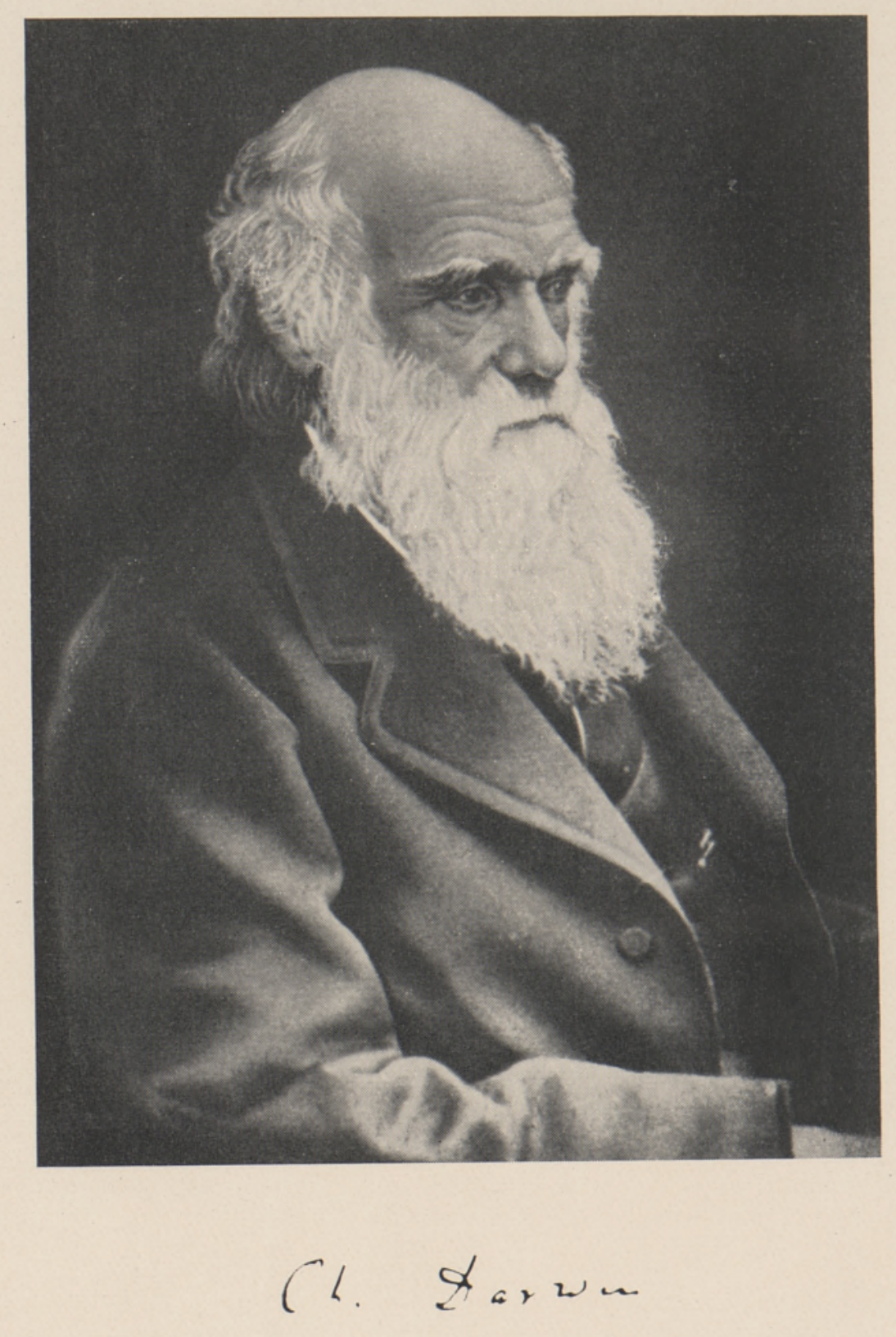


ИЗВЕСТИЯ АКАДЕМИИ НАУК ЭСТОНСКОЙ ССР. ТОМ VIII

СЕРИЯ БИОЛОГИЧЕСКАЯ. 1959, № 4

\title{
DARWINI OPETUS JA PÄRILIKKUSE SUUNATUD MUUTMISE PROBLEEM
}

\author{
O. PRIILINN, \\ põllumajandusteaduste kandidaat
}

24. novembril 1859. aastal, s. o. sada a astat tagasi, ilmus geniaalse looduseuurija Charles Darwini teos «Liikide tekkimine», mis tegi lõpu seni valitsenud vaadetele elava looduse muutumatusest. Selles töös esitatud evolutsiooniteooria pani kindla aluse bioloogiateaduse arenemisele. Evolutsiooni idee ei kuulu küll Darwinile, kuid Darwin kinnitas veenvalt suure faktilise materjali pōhjal elava looduse arenemist ja andis sellele igakülgse teadusliku põhjenduse.

Esmakordselt avaldati evolutsiooniprintsiip - orgaanilise maailma ajaloolise arenemise idee - küllalt selgelt Jean Lamarcki töös «Zooloogia filosoofia», mille ilmumise 150. aastapäeva tähistatakse käesoleval aastal koos darvinismi juubeliga. Lamarck kinnitas täiesti õigesti, et organismide muutumisel etendab juhtivat osa väliskeskkond; uued tunnused, mis tekivad organismide individuaalse elu jooksul, võivad päranduda edasi järgnevatele põlvkondadele. Kuid õigete seisukohtade kõrval esines tema ópetuses $\mathrm{ka}$ mehhanistlikke ja idealistlikke kontseptsioone, mille tôttu Lamarcki ideed tervikuna ei selgitanud evolutsiooniprotsessi tõelisi pōhjusi. Selle ülesande täitis hiilgavalt Charles Darwin oma loodusliku valiku teooriaga.

Raske oleks ülehinnata Darwini õpetuse tähtsust bioloogiateaduse arenemisele ja materialistliku maailmavaate kujunemisele. «Liikide tekkimises» näitas Darwin lihtsalt ja arusaadavalt ning teadusliku selgusega, et orgaanilise maailma kogu mitmekesisus on mitte «looja» tahte tulemus, vaid pika ajaloolisé arengu tagajärg. Oma loodusliku valiku teooriaga andis Darwin èlava looduse mitmekesisusele ja «otstarbekohasusele» materialistliku seletuse. Ta näitas rikkalike faktide alusel, et organismid muutuvad pikaajalises arenemisprotsessis ja et see mutumine viib uute vormide tekkele, mis oma ehituselt ja funktsioonidelt on kohanenud nende tingimustega, milles toimus arenemine.

Darwin oli muutlikkuse autogeneetiliste vaadete täielik vastane, eitades kategooriliselt igasuguseid idealistlikke vaateid organismide kalduvustest muutlikkusele ja sisemistest tendentsidest täiustumisele. Selles, et Darwin nägi muutlikkuse põhjusi üksnes elutingimuste muutumises, seisnebki tema vaadete üks tähtsamaid erinevusi Lamarcki vaadetest, kes arvas, et organismide muutumine ja täiustumine toimub ka muutumatutes keskkonnatingimustes sisemiste tegurite mõjul. Darwin tuli järeldusele, et kui looduses ei oleks pidevalt muutuvaid elutingimusi või kui oleks või- 
malik panna mingi liigi kõik isendid paljudeks põlvkondadeks absoluutselt ühesıgustesse tingimustesse, siis muutlikkust üldse ei esineks. ${ }^{1}$

Et Darwini järgi on looduslik valik võimetu midagi tegema ilma muutlikkuse ja pärilikkuseta, kuuluvad need lahutamatu osana loodusliku valiku teooriasse.

Töös «Liikide tekkimine» ei pööranud Darwin veel küllaldast tähelepanu elutingimuste otsesele mõjule organismide pärilikkuse muutumisel. Jagades muutlikkuse formaalselt kahte kategooriasse - kindlaks ja ebamääraseks muutumiseks - osutas Darwin viimasele evolutsioonis juhtiva koha. Kuid mida rohkem kogunes faktilist materjali, seda enam ta veendus välistingimuste otsese mōju tähtsuses. Oma järgmises suuremas töös — «Koduloomade ja kultuurtaimede muutumine» — rõhutab Darwin korduvalt elutingimuste otsest mõju muutlikkusele, pühendades sellele eri peatüki.

Seoses uute täiendavate faktide kogumisega räägib Darwin veendunult keskkonnatingimuste otsesest toimest organismide muutlikkusele. Ta kirjutab: «Suurim viga, mida ma olen teinud, seisneb minu arvates selles, et osutasin liiga vähe tähtsust ümbritseva keskkonna otsesele toimele, s. o. toidule, kliimale jne., sōltumata looduslikust valikust. ${ }^{2} \mathrm{Ja}_{\text {samas kirjas }}$ edasi märgib Darwin: «Kui ma kirjutasin «Liikide tekkimist» ja veel mõned aastad hiljem, leidsin vähe veenvaid tõendeid ümbritseva keskkonna otsesest toimest; nüüd on olemas palju tõendeid». Aja jooksul Darwin mōistis, kuivõrd ta oli valiku osa ülehinnanud ja elutingimuste tähtsust alahinnanud.

Oma elu eelviimasel aastal (1881) kirjutas Darwin, et «elutingimuste otsene toime organismile või nende muutumise põhjus on tulevikus kõige tähtsamaks küsimuseks.»3 Bioloogiateaduse arenemine pärast Darwinit on neid sōnu täielikult kinnitanud.

Kuna Darwini õpetus ei olnud kooskõlas valitseva kodanliku ideoloogiaga ja religioossete tõekspidamistega, tuli tal rajada teed visas võitluses idealistlike suundadega. Tema kaitseks astusid välja progressiivsed teadlased kogu maailmas, kelle hulgas kuulub eriline koht vene teadlastele (vennad A. O. ja V. O. Kovalevskid, I. M. Setšenov, A. N. Severtsov, K. A. Timirjazev jt.). Öigesti mõistis organismide evolutsiooniküsimusi materialistliku füsioloogia rajaja I. M. Setšenov, kes juba 1861. a. kirjutas, et organismi teaduslikku mõistesse kuulub ka keskkond, ilma milleta pole võimalik organismi olemasolu. ${ }^{4}$ Õigusega kuulub esikoht darvinismi propagandas ja kaitsemises K. A. Timirjazevile, kes tegi palju ka darvinismi edasiarendamise heaks.

Kõige ulatuslikumaks antidarvinistlikuks suunaks pärast Darwini surma kujunes veismanism-morganism, mis neodarvinismi sildi all kuulutas Darwini õpetuse vananenuks ja püüdis seda asendada nn. mutatsiooniteooriaga. Püstitanud muutlikkuse tunnetamatuse kontseptsiooni, kinnitasid neodarvinistid, et organismi muutused tekivad täiesti juhuslikult ja neid pole võimalik ette näha ega suunata, kusjuures pärilikud omadused arenevad sõltumatult keskkonnatingimustest.

Vaatamata taolistele teooriatele Darwini õpetus siiski levis ja kujunes juba pärast mōnede aastate möödumist juhtivaks õpetuseks bioloogias.

Kuid tolle aja teaduse ja pōllumajandusliku praktika tingimustes jäi inimene ikkagi ainult tekkivate muutuste valija ossa, suutmata sihipära-

1 Ч. Д а р в и н, Изменения домашних животных и культурных растений. Сочннення, т. 4. М., 1951 , lk. 643.

2 Ч. Д а р в н н, Избранные письма., И. Л. М., 1956, 1k. 251.

${ }^{3}$ Sealsamas, lk. 282.

${ }^{4}$ И. М. С еч е н о в, «Медицинский вестник», 1861, № 26, Jk. 242. 
selt ja plaanikindlalt esile kutsuda inimesele vajalikke muutusi. Eesrindlikumad taimesortide ja loomatõugude aretajad mõistsid väga hästi, et taimede ja loomade muutmise võti peitub nende olelustingimustes, kuid nad ei jõudnud organismide suunatud muutmise meetodite väljatöötamiseni.

Kunstliku valiku teooria ja praktika uus etapp on seotud suure vene bioloogi I. V. Mitšurini nimega.

Kuid juba enne Miť̌rinit seadis darvinismi klassik Timirjazev bioloogia ette uue ülesande. Ta ütles, et bioloog peab olema eksperimentaator, looduse juhtija. Bioloogia ülesandeks on uurida elu seadusi selleks, et õppida organisme muutma inimese huvides.

Mitšurini peaeesmärgiks kogu tema pika ning viljaka tööperioodi jooksul oli keskkonna mõju uurimine taimedele. Ta tuli järeldusele, et elutingimuste muutumine kutsub esile mitte juhuslikke muutusi organismide pärilikkuses, vaid neil muutustel on oma seaduspärane iseloom. Iga organism, alludes muutunud elutingimuste toimele, muutub vastavalt oma pärilikkusele, kuid alati adekvaatselt muutunud elutingimustele. Organism kui tervik kujuneb välja tihedas seoses väliskeskkonnaga. Mitšurin kirjutab, et «iga organismi iga organ, iga omadus, iga lüli, kõik sise- ja välisosad on tingitud tema olemasolu väliskeskkonnast. Kui taimeorganisatsioon on selline, nagu ta on, siis tuleb see sellest, et iga tema detail täidab teatud funktsiooni, mis on võimalik ja vajalik ainult antud tingimustel. Tarvitseb vaid neil tingimustel muutuda, osutub ka funktsioon vỗimatuks või tarbetuks ja seda teostav organ pikkamööda atrofeerub. $\aleph^{5}$

Enne Mitšurinit ei tuntud küllalt efektiivseid taimede loomuse mõjutamise ja suunatud muutmise meetodeid. Tol ajal levinud kunstliku valiku praktika piirdus pōhiliselt looduse enda poolt esilekutsutud muutuste kasutamisega ilma inimese suunava vahelesegamiseta. Lähtudes põllumajanduse praktika vajadustest ja toetudes Darwini evolutsiooniideele seadis Mitšurin endale ülesandeks plaanipäraselt aretada uusi taimede sorte. Praktilise aretustöö ja katsetuste käigus töötas Mitšurin välja tervikliku meetodite ja võtete süsteemi taimede pärilikkuse suunatud muutmiseks vastavalt inimese vajadustele, pannes sellega aluse teooriale orgaanilise maailma arenemise juhtimisest. Seega sai ta darvinismi arenemise kõrgema etapi - mitšuurinliku õpetuse — rajajaks.

Enne Mitšurini töid puudus teaduslik hübridiseerimisteooria. Mitšurin iseloomustas oma uurimistegevuse algusperioodil hübridiseerimise mõistet järgmiselt: «...hübridiseerimisteadust praegu ei ole olemas ning sõna «hübridiseerimine» tõlgitakse käesoleval ajal üldiselt arusaadavasse keelde järgmiste sõnadega: raputa, sega, lobise - midagi teistsugust tuleb välja.» ${ }^{6}$

Oma ja teiste aretajate töötulemuste sügava uurimise ja üldistamise tulemusena tuli Miť̌urin järeldusele, et ristamisel saadud hübriidide omadused olenevad nii ristatavate organismide pärilikkusest kui ka keskkonnatingimustest, milles toimusid ristamine ja hübriidse orgánismi edasine arenemine. Mitšurin nägi sordiaretuse peamist ülesannet mitte niivõrd ainult ristamises kuivõrd ristatavate taimede oskuslikus valikus ja hübriidsete seemikute suunatud kasvatamises. Eriti suurt tähtsust omistas Miť̌urin mentorile (kasvatajale) kui hübriidsete seemikute kasvatamise abinõule.

Mitšurini geneetilisest kontseptsioonist lähtudes ei ole pärilikkus mitte muutumatu omadus ega kujune lõplikult välja sügoodi moodustumisel,

5 I. V. Mitšurin, Valitud teosed. Tallinn, 1949, lk. 280.

6 И. В. М и ч у р н, Сочинения, т. 3. М., 1948, 자. 281 , 
vaid areneb individuaalsel kujul vastavalt seemiku arenemisele ja teda mõjutavatele tingimustele. Niisugune vaade pärilikkusele on saanud mitšuurinliku geneetika aluseks. Pärilikkuse- ja muutlikkuseküsimused on leidnud edasiarendamist Mitšurini järelkäijate, eelkõige akadeemik T. D. Lõssenko töödes.

Lähtudes F. Engelsi ideedest ja konkretiseerides neid on mitšuurinlik òpetus ulatusliku materjaliga kinnitanud, et ainevahetus on see, mis määrab kõik organismi elu- ja arenemisprotsessid. Organismi muutumine toimub seoses ainevahetuse muutumisega. Sattudes uutesse elutingimustesse muutub organismi ainevahetus ja selle kaudu ka pärilikkus. Kuid ainevahetuse muutumine ei kutsu üksnes esile organismi muutust, vaid määrab ära ka muutumise suuna. Selle eredaks näitajaks on vegetatiivsed hübriidid.

Darwin oli esimene, kes üldistas tol ajal kogunenud andmed vegetatiivse hübridiseerimise ala! ja tegi neist õiged järeldused. Ta leidis, et vegetatiivsel teel saadud hübriidid on väga sarnased sugulisel teel saadud hübriididega. Esitades rea andmeid vegetatiivse hübridiseerimise kohta, rōhutas Darwin, et «see fakt on erakordselt tähtis ja varem või hiljem muudab füsioloogide valated sugulisele reprodutseerimisele. $\$^{7}$ Vegetatiivse hübridiseerimise teooria ja praktika põhiküsimused on lahendatud Mitšurini poolt. Nüüd on nii Nõukogude Liidus kui ka paljudes teistes maades saadud tulemused taimede vegetatiivse hübridiseerimise alal laialdaselt tuntud. Nende uurimuste alusel on välja töötatud võtted, mis võimaldavad suunavalt mõjutada pookealuse ja poogendi omadusi ning nende generatiivseid järglasi. Vegetatiivse hübridiseerimise meetod on läinud kindlalt sordiaretuse praktikasse kui taimede suunatud muutmise meetod.

Muutunud elutingimuste suunavat mõju pärilike omaduste muutumisele näitavad kujukalt aklimatiseerimise alal tehtud tööd - lõunamaiste kultuuride viimine põhjapoolsetesse rajoonidesse, sealjuures põllunduse nihutamine äärmistesse polaartingimustesse. Näiteks Hibiinide (Koola poolsaarel) tingimustes tekkisid akadeemik J. Eichfeldi andmeil pika polaarpäeva ja teiste faktorite mõjul suured muutused taimesortide morfoloogilistes tunnustes ja hiljavalmivad sordid muutusid varavalmivaiks. ${ }^{8}$

«Tänu mitšuurinliku suuna arenemisele bioloogias,» ütleb akadeemik Lōssenko, «võib nüüd igaüks soovi korral ise veenduda selles, et taimede ja loomade pärilikke omadusi saab mitte ainult muuta, vaid ka suunavalt muuta, adekvaatselt väliskeskkonna tingimuste mōjutusele. $\aleph^{9}$

Võtame näiteks kas või suvinisu muutmise talinisuks ja vastupidi. Paljude autorite eksperimentaalsed uurimised viimaste aastate jooksul (ühtlasi ka Eestis) näitavad, et sügiskülvi tulemusena võib suvinisu $2-4$ aasta jooksul muutuda pärilikult talinisuks. Suvinisu taimede kasvu ja arenemise ajalooliselt väljakujunenud tüüp muudetakse välistingimuste otsesel mõjul stadiaalse arenemise käigus. Kuid formaalsed geneetikud püüavad tōestada, et elutingimuste suunava mōju tunnustamine tähendab loodusliku ja kunstliku valiku osa eitamist. Tegelikult ei tähenda see eitamist, vaid vastupidi - valiku loova osa rõhutamist.

Bioloogiateaduses on viimaste aastakümnete jooksul kogutud tohutı hulk fakte organismide kohanemismuutustest. Seda tõestas NSV Liidu Teaduste Akadeemia Geneetika Instituudi poolt 1957̈. aastal Suure Sotsia-

7 Ч. Д а р в ин, Изменения домашних животных и культурных растений. Сочинения,

т. 4. M., 1951, 涉. 415 .

8 J. E i ch f eld, Loov darvinism ja pōllumajanduse küsimused. Tallinn, 1948.

9 Т. Д. Лысенко, Дарвинизм живет и развивается. *Агробиология», 1959,

№ 5 , $1 k .653$. 
listliku Oktoobrirevolutsiooni 40. aastapäevale pühendatud üleliiduline konverents taimede, loomade ja mikroorganismide pärilikkuse ja muutlikkuse küsimustes. Konverentsil esitatud ettekannetes ja rohketes sõnavōttudes leidis täielikku kinnitust fakt, et organismi pärilikkuse muutumine ei ole mitte juhuslik ja ebamäärane, vaid toimub täiesti seaduspäraselt, vastavalt elutingimuste muutumisele. Eriti palju uusi andmeid esitati mikroorganismide kohta, mis kinnitab mitšuurinliku õpetuse õigsust.

Vastandina veismanismile-morganismile on mitšuurinlik ỏpetus, juhindudes dialektilise materialismi põhialustest, tōestanud praktikas, et organismide muutumise aluseks on objektiivsed seaduspärasused, mida vōib tunnetada ja suunata. Bioloogia ülesandeks on vōimalikult sügavamalt neid tundma óppida. Toetudes avastatud seaduspärasustele suutis Mitšurin oma eluaja jooksul aretada üle 300 mitmesuguse taimesordi. Mitšuurinlikud aretusmeetodid leiavad järjest laialdasemat rakendamist pōllumajanduse praktikas, niihästi taimekasvatuses kui ka loomakasvatuses. Darvinismi arenemise mitšuurinliku etapi tähtsamaks jooneks on teooria ja praktika ühtsus.

Organismide suunatud muutlikkuse probleem on kaasaegses bioloogias kujunenud keskseks. Selle juhtivaks printsiibiks on organismide poolt nende elıaja jooksul omandatud tunnuste ja omaduste pärandatavus. Ometi leidub käesolevalgi ajal biolooge, kes eitavad omandatud tunnuste ja omaduste pärandatavust ning välistingimuste mõju pärilikkusele. Sellega ignoreerivad nad ühtlasi elava looduse arenemise objektiivseid seaduspärasusi. Näiteks märgib tuntud formaalse geneetika esindaja C. D. Darlington oma artiklis «Darwin ja geneetika»10, et ebaõnnestumiseks Darwini teoorias on pärilikkuseprobleemi lahendamine, s. o. omandatud tunnuste pärandatavuse ja väliskeskkonna faktorite mõju tunnustamine. Ameerika professor, geneetik ja kirikutegelane J. Klotz kirjutab 1955. aastal: «Meil tuleb tänada loojat, et pole olemas omandatud tunnuste pärandamist.»11 Niisuguseid näiteid võiks veelgi tuua.

Kahjuks leidub analoogilisi seisukohti isegi veel meie kirjanduses. Võiks märkida mõningaid artikleid peamiselt ajakirja «Ботанический журнал» viimaste aastate numbritest. Asi läks isegi nii kaugele, et hakati eitama omandatud tunnuste pärandamise printsiipi ja väliskeskkonna otsest mõju pärilikkusele. Näiteks nimetab A. Tahtadžjan omandatud tunnuste pärandamist «dogmaks» ja «absurdsuseks», ülistades morganismi. ${ }^{12}$ Evolutsiooniprotsessi püüab ta seletada autogeneesi vaimus.

Uldiselt on aga autogeneesi-ideede pooldajate tõekspidamistes märgata muutumistendentsi.

Näiteks vastupidi oma varasematele seisukohtadele on N. Dubinin oma viimastes artiklites tunnistanud, et pärilikud muutused olenevad mõjutava faktori kvaliteedist ja et seni laialt levinud vaade mutatsiooniprotsessist kui spontaansest nähtusest nõuab tõsist revideerimist. ${ }^{13}$ Mutatsiooni juliuslikkuse printsiip tuleb nüüd Dubinini sõnade järgi asendada mutatsiooni printsipiaalse sõltuvuse tunnustamisega väliskeskkonna mõju iseloomust.

Praktikas kinnituse leidnud teooria rajab endale alati tee. Nii on ka Darwini ideedele baseeruva mitšuurinliku õpetusega. Ta leiab järjest laiemat pinda mitte ainult rahvademokraatiamaades, vaid ka kodanlikes riiki-

${ }^{10}$ C. D. D a rling to n, Darwin and Genetics. «New Scientist», 4, 1958, No. 84, 1k. $255-257$.

$11 \mathrm{~J}$. K lotz, Genes, Genesis and Evolution. 1955.

12 А. Л. Т а хт а жж ян, Прямое приспособление или естественный отбор? «Ботачнческий журнал», 1957, № 4.

${ }^{13}$ Н. П. Дубин и н, Об основных факторах естественного мутационного процесса. «Ботаническнй журнал», 1958, № 8. 
des, tõrjudes välja formaalse geneetika seisukohad. Nii näiteks kirjutab prantsuse ajakiri «Atomes», et «Mitšurini teooria kujutab endast faktiliselt loogilist ja tervet ideed, kuna ainevahetuse rikkumine väliskeskkonna muutumise mõjul võib mõjutada organismi pärilikkust, samal ajal kui klassikaline geneetika vastupidiselt arvab, et pärilikud faktorid on kaitstud väliskeskkonna mõju eest kindluse ligipääsmatute seintega, s. o. rahu tuumaga.»14

Küllaltki selge pildi geneetika arenemise tendentsidest välismaal annavad 1958. aastal Montrealis toimunud X rahvusvahelise geneetika kongressi materjalid. On tähelepanuväärne, et mitte ükski teaduslikus kirjanduses tuntumaid geneetikuid ei pidanud vajalikuks esineda kongressil ettekandega, mis oleks spetsiaalselt pühendatud mitšuurinlike seisukohtade kriitikale. ${ }^{15}$ Kuid veel neli-viis alastat tagasi esineti välismaal tuliselt mitšuurinliku suuna vastu.

Paljude maade teadlased kandsid kongressil ette oma uurimistöö tulemusi vegetatiivse hübridiseerimise, vereülekande ja teiste probleemide alalt. Need tööd kinnitavad mitšuurinliku bioloogia poolt juba varem tehtud järeldusi. Suur hulk ettekandeid oli pühendatud taimede pärilikkuse muutumise küsimustele seoses elutingimuste muutmisega.

Nōukogude geneetikute ettekandeid kuulas kongress suure huviga, mida märgiti ka kodanlikes ajalehtedes.

Tehes kokkuvõtteid X rahvusvahelisest geneetikute kongressist kirjutab A. Mc Laren inglise ajakirjas «Discovery» ${ }^{16}$, et Montrealis esitatud andmed sunnivad neid revideerima seniseid vaateid tunnuste pärilikkuse kohta. Meenutades inimese ammust unistust muuta suunavalt taimede ja loomade pärilikkust, märgib Mc Laren, et Montreali kongressil nähtavasti purustati «juhuslikkuse barjäär».

Võib täiesti ühineda I. Gluštšenko väitega, et kõik, mida morganistlik geneetika veel hiljuti ei tunnustanud ja kỗrvale heitis, esmajoones suunatud muutlikkuse probleem, on muutunud tänapäeval välismaiste geneetikute tähelepanu keskpunktiks. ${ }^{17}$

Käesolevas lühikeses ülevaates on võimalik organismide pärilikkuse suunatud muutmise tähtsamaid küsimusi vaid kõige üldisemal kujul valgustada. Esitatust nähtub aga, et tänapäeva bioloogiateaduse tähtsamat ülesannet - suunata organismide muutlikkust - täidetakse edukalt. Siinjuures meenuvad Darwini sōnad «Liikide tekkimise» viimastel lehekülgedel: «Avaneb määratu suur ja peaaegu puutumatu väli muutlikkuse pōhjuste ja seaduste uurimiseks,.... Uus, inimese poolt aretatud teisend kujutab endast palju huvitavamat ja tähtsamat uurimisobjekti kui veel ühe liigi lisamine juba loetelusse kantute lōputusse hulka.» ${ }^{18}$

Vaatamata sellele, et Darwini peateose ilmumisest on möödunud juba terve sajand, tungivad seal esitatud mõtted järjest sügavamalt inimese teadvusse, valgustades teed elava looduse tunnetamiseks ja suunatud muutmiseks.

Nõukogude bioloogid-mitšuurinlased, taime- ja loomakasvatajad ning aretajad hindavad kōrgelt Darwini teeneid, kes uskus inimese kui taimeja loomariigi ümberkujundaja loovasse jõusse, tema suurtesse perspektii-

14 F. G rigu i, Nouvelles enignes de la Genetique Sovietique. «Atomes», 1958, No. 2.

15 В. Н. Столетов, Десятый международный генетический конгресс. «Вестник сельскохозяйственной науки», 1959, № 2.

${ }_{16}$ Anne M c L a re n, International Scientific Meetings: Montreal: Congress of Genetics. «Discovery», XIX, 1958.

17 И. Г. Глушенко, Заметки о десятом международном конгрессе генетиков. «Агробиология», 1958, № 6, 1k. 154.

18 Ч. Д а р в н Н, Пронсхождение видов. М., 1952, llk. $447-448$. 
videsse täiustada olemasolevaid ja aretada uusi taimesorte ning loomatõuge.

Mitšuurinlik suund kui darvinismi loov arendamine kaasaegses bioloogias on saanud kogu maailma bioloogide tähelepanu keskpunktiks. Organismi ja tema elutingimuste ühtsuse idee, s. o. lahutamatu seose tunnustamine elavate organismide ja neid ümbritseva keskkonna vahel, avaldab sügavat mõju materialistliku maailmavaate ja bioloogiateaduse arenemisele. Bioloogidele kogu maailmas saab järjest selgemaks see, et orgaanilise malailma arenemise ja suunatud muutmise teooriat ei saa arendada edasi, arvestades ainult arenemise sisemisi tegureid ja ignoreerides neid määravaid tingimusi. "Loodusteadus on oma olemuselt materialistlik, materialism ja selle juured peituvad looduses. Loodusteadus kisub stiihiliselt dialektika poole. Väärarusaamade vältimiseks mõistete omandamisel on tarvis tunda ainuõiget filosoofiat - dialektilise materialismi filosoofiat,» ütleb Mitšurin. ${ }^{19}$

Mitšuurinliku bioloogia edusammud organismide muutlikkuse põhjuste uurimisel ja pärilikkuse suunatud muutmise probleemi lahendamisel on seletatavad eelkõige sellega, et mitšuurinlik bioloogia toetub dialektilisele materialismile ja kogu eelnevale bioloogiateaduse arengule, eriti Darwini surematule õpetusele, ning on tihedalt seotud sotsialistliku põllumajanduse praktikaga.

Ei ole kahtlust selles, et organismide lainevahetusprotsesside ja pärilikkuse seaduspärasuste edasine igakülgne tundmaõppimine uute tehniliste ja metoodiliste võimaluste juures võimaldab juba kõige lähemas tulevikus veelgi suurendada inimese võimu elava looduse üle.

19. I. V. Mitšuri n, Valitud teosed. Tallinn, 1949, lk. 513. 